\title{
Panorama do Uso da Cefalometria por Especialistas em Ortodontia no Estado do Rio Grande do Sul
}

\author{
Panorama of the Use of Cephalometry by Orthodontists in Rio Grande do Sul - South Brazil
}

Heraldo Luis Dias Silveira1, Gabriela Salatino Liedke², Bruno Rivaldo Rybu³, Reni Raymundo Dalla-Bona ${ }^{4}$, Heloísa Emilia Dias Silveira ${ }^{5}$

\section{Resumo}

A análise cefalométrica é um dos exames utilizados para o diagnóstico e planejamento de um tratamento ortodôntico. Com o objetivo de avaliar o uso que os profissionais fazem da cefalometria, foram enviados questionários a todos os especialistas em Ortodontia e Ortopedia Facial do estado do Rio Grande do Sul. Os resultados mostram que a maioria dos profissionais $(96,4 \%)$ solicita o exame ao início de todos os tratamentos ortodônticos, apenas a metade $(50,4 \%)$ solicita-o no final. Ainda, que a maioria $(88,3 \%)$ valoriza mais o perfil do paciente no estabelecimento do plano de tratamento e apenas $19,2 \%$ dos profissionais declararam conferir os cefalogramas recebidos das clínicas. A partir dos resultados conclui-se que a maioria dos especialistas em Ortodontia e Ortopedia Facial no Estado do Rio Grande do Sul solicita a análise cefalométrica computadorizada Padrão USP ao início de todos os tratamentos ortodônticos, considera o perfil do paciente determinante para a escolha da conduta a ser seguida e não questiona os cefalogramas enviados pelas clínicas de radiologia.

Palavras-chave: Cefalometria.

\begin{abstract}
Cephalometric analysis is one of the approaches employed to diagnose and plan orthodontic treatment. Aiming to assess the manner orthodentists utilize cephalometry, questionnaires were sent to all specialists on Orthodontics and Facial Orthopedics working in the state of Rio Grande do Sul, south Brazil. The results show that the exam is requested by the majority of the professionals $(96.4 \%)$ as of the beginning of orthodontic treatments, and by only half $(50.4 \%)$ at the end of treatment. Also, most orthodontists $(88.3 \%)$ put great value to the patient profile in defining treatment strategies and only $19,2 \%$ reported checking the cephalograms they receive. The results afforded to conclude that most specialists on Orthodontics and Facial Orthopedics working in Rio Grande do Sul request computerized cephalometric analysis according to the USP standard at the beginning of all orthodontic treatments, and considers patient profile as a determining factor in the choice of the approach to the treatment. Moreover, cephalograms produced by radiography centers are not mistrusted.
\end{abstract}

Keywords: Cephalometry.
${ }^{1}$ Doutor em Odontologia, Professor Permanente do Programa de Pós-Graduação em Odontologia, UFRGS

\footnotetext{
${ }^{2}$ Mestre em Clínica Odontológica/ Radiologia UFRGS

${ }^{3}$ Cirurgião-dentista graduado pela FO-UFRGS

${ }^{4}$ Doutor em Gerontologia; Professor Associado de Radiologia do Departamento de Cirurgia e Ortopedia

5 Doutora em Odontologia; Professora Permanente do Programa de PósGraduação em Odontologia, UFRGS
}

Correspondência: Gabriela Salatino Liedke

Endereço: Rua Ramiro Barcellos, 2492 - CEP 90035003, Porto Alegre - RS, Brasil

Fone: 3308-5199

E-mail: gabiliedke@yahoo.com.br

Data de submissão: 24/04/2009

Data de aceite: 14/10/2009

\section{Introduction}

Radiographic cephalometry is an important resource in the diagnosis, planning and follow-up of orthodontic, facial-orthopedic or surgical-orthognathic treatment (FONSECA, 2001). Cephalograms provides images of the osseous, dental and tegumental structures with negligible amplification or deformation. In the conduction of cephalograms there is the specific characteristic of reproducing the exact execution conditions in successive exams of one same patient, so as to afford the superimposition of films with the best accuracy possible (ARAÚJO, 1983).

The main objective of orthodontic treatment is the improvement of function, dentofacial esthetics, and patient selfimage (PROFIT; ACKERMAN, 1985). Therefore, a detailed evaluation of the soft profile of the patient's face is an important routine step in the diagnostic and definition of the treatment approach (HOLDAWAY, 1983). In the light of the contradictions between the cephalometric landmarking and clinical examination of patient profile, the specialist is inclined to trust more the profile itself than cephalometry, under the concern to treat the patient from the esthetic standpoint.

The analysis of the profile is also directly linked to the decision to extract or not any teeth during orthodontic treatment. Favorable changes in patient profile may be accomplished by means of the extraction of premolars, though it is important to take into account the unfavorable changes that may take place when the individual diagnosis is not conducted. Researchers have observed the inter-examiner variations in the identification of cephalometric landmarks involving incisors, by means of the discrepancies of Tweed and Vigorito (SILVEIRA et al., 2004). Variations of $4 \mathrm{~mm}$ or more were observed in both analysis methods, a result that may lead to erroneous interpretations and decision-making, and ultimately to unnecessary extractions that put the expected results of treatment at risk.

In this scenario and considering the importance of cephalometric analysis to the diagnosis and treatment course, this study aimed to depict a panorama of the use of cephalometry by specialists on Orthodontics and Facial Orthopedics in the state of Rio Grande do Sul, south Brazil. 


\section{Methods}

A structured questionnaire about use of cephalometry was sent by mail to all the 476 specialists on Orthodontics and Facial Orthopedics registered in the State Council of Orthodontics, and working in the state of Rio Grande do Sul, Brazil. All dentists signed an informed consent form that was sent with the questionnaire and delivered separately. This study was approved by the Ethics Committee of UFRGS Dental School (number 52/05). A descriptive analysis of the results was made in order to construct a picture of the use of cephalometry by those specialists. Of the 9 questions of the questionnaire, 6 were based on the 5-point Likert scale.

\section{Results}

Of the 476 questionnaires sent, 170 were answered. The results point to the agreement among orthodontists as to the importance of cephalometric analysis for the diagnosis, planning and follow-up in orthodontic treatment (Table 1). Almost all (96.4\%) of the specialist require this complementary investigation at the beginning of all orthodontic treatments and only half do so at the end of treatments $(50.4 \%)$.

The main aspect the orthodontist relies on to define the treatment approach is the patient profile: $88.3 \%$ of these professionals stated that they do in fact value more the patient profile than cephalometric analysis in the definition of diagnosis and treatment strategies. Similarly, in the borderline cases in which total discrepancy between patient profile and cephalometry is observed, the decision to extract teeth is not influenced by the results of cephalometric investigations.

In the state of Rio Grande do Sul, cephalometric analyses are mainly executed by radiology centers $(82.5 \%)$, with the computerized method being the most used (83.2\%). The cephalometric analysis most requested by specialists is the USP Standard cephalometry (45.1\%), followed by McNamara (16.2\%), Ricketts (14.6\%) and Steiner (7.4\%).

Orthodontists do not have the habit of check landmarks and/or reorder cephalometric analyses. Only 19.2\% reported checking the cephalograms they receive, with $41.5 \%$ verify cephalometric landmarks only when they suspect that some mistake was made.

Table 1. Agreement between specialists to the questions about the use of cephalometry.

\begin{tabular}{ccccccc}
\hline \multicolumn{7}{c}{ Questions: level of agreement * } \\
\hline$\%$ & 1 & 2 & 3 & 4 & 5 & 6 \\
Agree & 89.0 & 96.4 & 50.4 & 26.1 & 9.0 & 88.3 \\
Unsure & 6.6 & 2.1 & 19.6 & 41.5 & 67.6 & 8.8 \\
Disagree & 4.4 & 1.5 & 30.0 & 32.3 & 23.4 & 2.9 \\
\hline
\end{tabular}

*1 - Do you consider cephalometry to be an important complementary exam for diagnosis, planning and follow-up purposes in orthodontic treatment? 2 - Do you usually request cephalometric analyses at the beginning of all orthodontic treatments? 3 - Do you request cephalometric analyses at the end of all orthodontic treatments? 4-Do you usually check landmarks and/or require new cephalometric analysis for your patients? 5 - In the extreme cases of total discrepancy do you choose to extract teeth? 6 - Do you value patient profile more in the definition of diagnosis and treatment approach as compared to cephalometric analyses?

Rev. Fac. Odontol. Porto Alegre, v. 50, n. 2, p. 5-7, mai./ago., 2009.

\section{Discussion}

Cephalometry is an objective evaluation of measurable values, oppositely to clinical examination, which is mostly of a subjective character. An orthodontist who rules out cephalometry from routine clinical activities is actually working without any direction or reliable clue, and should not be called a scientist (LANGLADE, 1993). The results of the present research show that most orthodontists in the state of Rio Grande do Sul agree with this statement, as $89 \%$ consider cephalometric analyses to be very important to the diagnosis, planning and follow-up of orthodontic treatment.

Nevertheless, of the $96.4 \%$ of orthodontists who request cephalometric investigations at the beginning of orthodontic treatments, only half do so also at the end of the treatment period. It should be remembered that cephalometry is important not only for the diagnosis, but also for the orthodontic evaluation and treatment. In many cases, the appropriate diagnosis may be achieved without the assistance of a cephalogram. Yet, it becomes virtually impossible to accurately assess responses to treatment and changes underlying patient growth that can be observed in a series of lateral cephalograms (YOU; HAGG, 1999).

Numerous kinds' analyses are available to the orthodontist, and each professional or research center resorts to that which is most appropriate to the individual work or study approach in question. The USP Standard, which includes measurements conducted in accordance to the Steiner and Tweed analytical protocols, is the preferred form, by $45.1 \%$ of the orthodontists of Rio Grande do Sul.

As esthetics is an essential aspect for the patient in orthodontic treatments, orthodontists agree with several authors $(\mathrm{HOHI}$ et al., 1978; HOLDAWAY, 1983; PROFIT; ACKERMAN 1985 ) and also tend to place greater value to the clinical profile of the patient than to the cephalometric investigation. Similarly, the decision to include tooth extractions in the treatment approach is not exclusively based on the information offered in the cephalogram. Tooth extractions, especially of the first premolars, has contributed to change uneven profiles (convex - biprotruded) to more harmonic ones (HOFFELDER et al., 2004). Yet, it is known that total discrepancy observed in the cephalometric investigation may lead to the unnecessary tooth extraction and thus to undesired changes in the profile (SILVEIRA et al., 2004).

The value of cephalometric analysis depends considerably on the precision of the recording and measurement techniques that when incorrectly performed, may lead to wrong diagnosis (STABRUN; DANIELSEN, 1982; BATTAGEL, 1993; TNG et al., 1994; RUDOLPH; SINCLAIR et al., 1998; TRENOUTH, LAITUNG; NAFTEL, 1999). With the arrival of computerized cephalometry, mistakes in measurements are more consistently minimized (ONGKOSUWITO et al., 2002). However, mistakes in landmarking, since they depend on subjective concepts regarding definition and perception, still persist (LAU; COOKE; HAGG, 1997). Most cephalometric analyses used by orthodontists in the state of Rio Grande do Sul are conducted in radiology centers, which adopt the computerized method. Researchers have demonstrated the lack of reproducibility of values presented in lateral cephalometric analysis conducted in different radiology centers in the city of Porto Alegre, Rio Grande do Sul (SILVEIRA; SILVEIRA, 2006). This study reveals that the orthodontists do not check the cephalograms they request from the radiology centers. Therefore, there is the possibility that these analysis present mistakes, and that these mistakes are being ignored by orthodontists in the diagnosis and definition of treatment strategies for their patients.

\section{Conclusion}

Most Orthodontics and Facial Orthopedics specialists working in the state of Rio Grande do Sul (i) request computerized cephalograms according to the USP standard at the beginning of all 
orthodontic treatments, (ii) consider patient profile a determining aspect concerning treatment choice approach, and (iii) do not disagree with cephalometric investigations made by radiology centers.

\section{References}

ARAÚJO, T. M. Cefalometria, conceitos e análises, 1983. 304 f. Dissertação (Mestrado em Odontologia) - Faculdade de Odontologia, Universidade Federal do Rio de Janeiro, Rio de Janeiro.

BATTAGEL, J. M. A comparative assessment of cephalometric errors. Eur. J. Orthod., Switzland, v. 15, no. 4, p. 305-314, Aug.1993.

FONSECA, R. C. Análise cefalométrica, diagnóstico e planejamento ortodôntico. São Paulo: Santos, 2001. 358 p.

HOFFELDER, L. B. et al. Alterações no perfil facial tegumentar decorrentes da extração de primeiros pré-molares. R. Odonto $\mathbf{C i}$., Porto Alegre, v. 19, no. 43, p. 51-56, Jan./Mar. 2004.

$\mathrm{HOHI}, \mathrm{T}$. H. et al. Craniofacial ostetomies: a photocephalometric technique for the prediction and evaluation of tissue changes. Angle Orthod., Chicago, v. 48, no. 2, p. 114-125, Apr. 1978.

HOLDAWAY, R. A. A soft-tissue cephalometric analysis and its use in orthodontic treatment planning. Part I. Am. J. Orthod., St. Louis, v. 84, no.1, p. 1-28, July 1983.

LANGLADE, M. Cefalometria ortodôntica. São Paulo: Santos, 1993. $269 p$

LAU, P. Y.; COOKE, M. S.; HAGG, U. Effect of training and experience on cephalometric measurement errors on surgical patients. Int. J. Adult. Orthod. Orthognath. Surg., Chicago, v. 12, no. 3, p. 204-213, 1997.

ONGKOSUWITO, E. M. et al. The reproducibility of cephalometric measurements: a comparison of analogue and digital methods. Eur. J. Orthod., Switzland, v. 24, no. 6, p. 655-665, Dec. 2002.

PROFIT, W. R.; ACKERMAN, J. L. Diagnosis and treatment planning in orthodontics. In: GRABER, T.M.; SWAIN, B.F. Orthodontics: current principles and techniques, St Louis: Mosby Company, 1985. Cap. 15, p. 3-87.

RUDOLPH, D. J.; SINCLAIR, P. M.; COGGINS, J. M. Automatic computerized radiographic identification of cephalometric landmarks. Am. J. Orthod. Dentofacial Orthop., St. Louis, v. 113, no. 2, p. 173-179, Feb.1998.

SILVEIRA, H. L. D. et al. Avaliação cefalométrica de medidas envolvendo os incisivos por diferentes examinadores e sua relação com o tratamento ortodôntico. R. Odonto Ci., Porto Alegre, v. 19, no. 44 , p. $152-156$, Apr. 2004

SILVEIRA, H. L.; SILVEIRA, H. E. Reproducibility of cephalometric measurements made by three radiology clinics. Angle Orthod., Chicago, v. 76, no. 3, p. 394-399, May 2006.

STABRUN, A. E.; DANIELSEN, K. Precision in cephalometric landmark identification. Eur. J. Orthod., Switzland, v. 4, no. 3, p. 185-196, Aug. 1982.

TNG, T. T. et al. Validity of cephalometric landmarks. An experimental study on human skulls. Eur. J. Orthod., Switzland, v. 16, no. 2, p. 110-120, Apr. 1994.
TRENOUTH, M. J.; LAITUNG, G.; NAFTEL, A. J. Differences in cephalometric reference values between five centres: relevance to the Eurocleft Study. Br. J. Oral Maxillofac. Surg., Edinburgh, v. 37, no. 1, p. 19-24, Feb. 1999.

YOU, Q. L.; HAGG, U. A comparison of three superimposition methods. Eur. J. Orthod., Switzland, v. 21, no. 6, p. 717-725, Dec. 1999. 